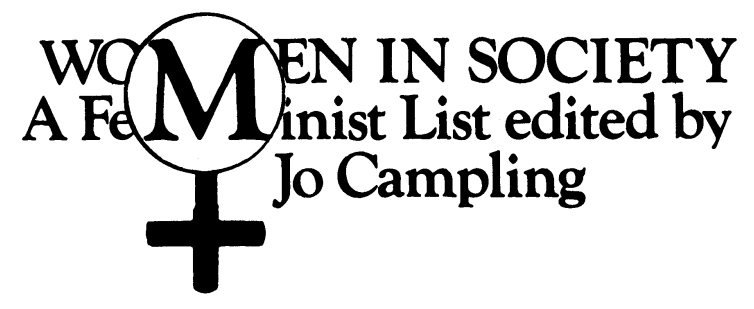

editorial advisory group

Maria Brenton, University College, Cardiff; Phillida Bunckle, Victoria University, Wellington, New Zealand; Miriam David, Polytechnic of the South Bank; Leonore Davidoff, University of Essex; Janet Finch, University of Lancaster; Jalna Hanmer, University of Bradford; Beverley Kingston, University of New South Wales, Australia; Hilary Land, Royal Holloway and Bedford New College, University of London; Diana Leonard, University of London Institute of Education; Susan Lonsdale, Polytechnic of the South Bank; Jean O'Barr, Duke University, North Carolina, USA; Arlene Tigar McLaren, Simon Fraser University, British Columbia, Canada; Jill Roe, Macquarie University, Australia; Hilary Rose, University of Bradford; Susan Sellers, Centre D'Etudes Féminines, Université de Paris; Pat Thane, Goldsmiths' College, University of London; Jane Thompson, University of Southampton; Clare Ungerson, University of Kent at Canterbury; Judy Walkowitz, Rutgers University, New Jersey, USA.

The 1970s and 1980s have seen an explosion of publishing by, about and for women. This new list is designed to make a particular contribution to this process by commissioning and publishing books which consolidate and advance feminist research and debate in key areas in a form suitable for students, academics and researchers but also accessible to a broader general readership.

As far as possible books will adopt an international perspective incorporating comparative material from a range of countries where this is illuminating. Above all they will be interdisciplinary, aiming to put women's studies and feminist discussion firmly on the agenda in subject-areas as disparate as law, physical education, art and social policy. 


\section{WN IN SOCIETY
inist List edited by
Jo Campling}

Published

Sheila Allen and Carol Wolkowitz Homeworking: myths and realities

Jenny Beale Women in Ireland: voices of change

Angela Coyle and Jane Skinner (editors) Women and Work: positive action for change

Gillian Dalley Ideologies of Caring: rethinking community and collectivism

Leonore Davidoff and Belinda Westover (editors) Our Work, Our Lives, Our Words: women's history and women's work

Emily Driver and Audrey Droisen (editors) Child Sexual Abuse: feminist perspectives

Diana Gittins The Family in Question: changing households and familiar ideologies

Frances Heidensohn Women and Crime

Ursula King Women and Spirituality: voices of protest and promise

Muthoni Likimani (Introductory Essay by Jean O'Barr) Passbook Number F.47927: women and Mau Mau in Kenya

Jo Little, Linda Peake and Pat Richardson (editors) Women in Cities: gender and the urban environment

Sharon Macdonald, Pat Holden and Shirley Ardener (editors) Images of Women in Peace and War: cross-cultural and historical perspectives

Shelley Pennington and Belinda Westover A Hidden Workforce: homeworkers in England, 1850-1985

Vicky Randall Women and Politics: an international perspective (2nd edn)

Rosemary Ridd and Helen Callaway (editors) Caught Up in Conflict: women's responses to political strife

Patricia Spallone Beyond Conception: the new politics of reproduction

Taking Liberties Collective Learning the Hard Way: women's oppression in men's education

Clare Ungerson (editor) Women and Social Policy: a reader

Annie Woodhouse Fantastic Women: sex, gender and transvestism

\section{Forthcoming}

Eileen Aird and Judy Lown Education for Autonomy: processes of change in women's education Niamh Baker Happily Ever After? Womens's fiction in postwar Britain, 1945-60

Jennifer Breen Women and Fiction

Maria Brenton Women and Old Age

Joan Busfield Women and Mental Health

Ruth Carter and Gill Kirkup Women in Engineering

Lesley Ferris Acting Women: images of women in theatre

Tuula Gordon Feminist Mothers

Frances Gray Women and Laughter

Eileen Green, Diana Woodward and Sandra Hebron Women's Leisure, What Leisure?

Jennifer Hargreaves Women and Sport

Annie Hudson Troublesome Girls: adolescence, femininity and the state

Susan Lonsdale Women and Disability

Mavis Maclean Surviving Divorce: women's resources after separation

Lesley Rimmer Women's Family Lives: changes and choices

Susan Sellers Language and Sexual Difference: feminist writing in France

Deborah Valenze The Other Victorian Women

Janet Wolff The Art of Women 


\title{
Child Sexual Abuse
}

Feminist Perspectives

\author{
Edited by \\ Emily Driver and \\ Audrey Droisen
}

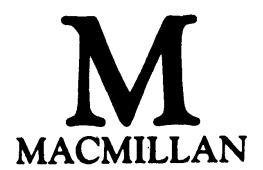


Selection and editorial matter (C) Emily Driver and Audrey Droisen 1989 Introduction, Chapters 3 and 6 (C) Emily Driver 1989

Chapters 1 and 5 (C) Audrey Droisen 1989

Chapter 2 (C) Cathy Waldby, Atosha Clancy, Jan Emetchi and

Caroline Summerfield 1989

Chapter 4 (C) Simmy Viinikka 1989

All rights reserved. No reproduction, copy or transmission of this publication may be made without written permission.

No paragraph of this publication may be reproduced, copied or transmitted save with written permission or in accordance with the provisions of the Copyright Act 1956 (as amended), or under the terms of any licence permitting limited copying issued by the Copyright Licensing Agency, 33-4 Alfred Place, London WC1E 7DP.

Any person who does any unauthorised act in relation to this publication may be liable to criminal prosecution and civil claims for damages.

First published 1989

Published by

MACMILLAN EDUCATION LTD

Houndmills, Basingstoke, Hampshire RG21 2XS

and London

Companies and representatives

throughout the world

British Library Cataloguing in Publication Data

Child sexual abuse: feminist perspectives

- Women in Society

1. Children. Sexual abuse

I. Driver, Emily II. Droisen, Audrey

III. Series

362.7 '044

ISBN 978-0-333-44246-3

ISBN 978-1-349-20020-7 (eBook)

DOI 10.1007/978-1-349-20020-7 
Man to man is so unjust

Children

Don't know who to trust

Your worst enemy could be your best friend

And your best friend, your worst enemy

Some will eat and drink with you

Then behind, them suss upon you . . .

... So who the cap fit, let them wear it.

Bob Marley, Who the Cap Fits

The right to affection, love and understanding

The right to adequate nutrition and medical care

The right to full opportunity for play and recreation

The right to a name and nationality

The right to special care, if handicapped

The right to be among the first to receive relief in times of disaster

The right to learn to be a useful member of society and to develop individual abilities

The right to be brought up in a spirit of peace and universal brotherhood

The right to enjoy these rights, regardless of race, colour, sex, religion, national or social origin

UN Declaration of the Rights of the Child 


\section{Contents}

Acknowledgements $x$

Notes on the contributors $\quad x i$

Introduction 1

Emily Driver

Definitions $\quad 2$

Consent 4

Sexual abuse by boys $\quad 6$

Sexual abuse by females $\quad 8$

The characteristics of a sex offender 9

$\begin{array}{ll}\text { Familial v. non-familial abuse? } & 17\end{array}$

The politics of child abuse $\quad 20$

The traditional Western mythology of child sexual abuse 26

Professional treatment of child sexual abuse $\quad 44$

$\begin{array}{ll}\text { Education } & 51\end{array}$

The law $\quad 53$

Racism and anti-Semitism $\quad 56$

$\begin{array}{lr}\text { Positive action } & 57\end{array}$

1 Some biographies

Audrey Droisen (compiler)

Siân $\quad 70$

Debbie $\quad 71$

$\begin{array}{ll}\text { Diane } & 76\end{array}$

$\begin{array}{ll}\text { Mrs. Sullivan } & 78\end{array}$

Kris $\quad 81$

$\begin{array}{ll}\text { Effie } & 82\end{array}$

Ellen $\quad 84$

$\begin{array}{ll}\text { Robert } & 86\end{array}$ 


\section{viii Contents}

2 Theoretical perspectives on father-daughter incest

Cathy Waldby, Atosha Clancy, Jan Emetchi and Caroline

Summerfield for Dympna House

The psychiatric literature

Family dysfunction literature $\quad 93$

The psychological literature $\quad 95$

The feminist literature $\quad 97$

The power theory 101

3 Through the looking glass: children and the professionals who treat them

Emily Driver

The initial confusion

The distancing response

The quest for safety

Identification with the aggressor

Some suggested solutions

4 Child sexual abuse and the law

Simmy Viinikka

Criminal statistics

Legal definitions

Legal intervention

The offender

Types of offence

Legislative change

Investigation

Evidence

Court proceedings

The balance of power

Sentencing policy

Punishment or treatment?

Conclusion

5 Racism and anti-Semitism 158

Audrey Droisen

Historical background

Stereotyping

Echoes of abuse

Being an outsider

Protecting the community 
Contents ix

Protecting the child 164

$\begin{array}{ll}\text { Training } & 166\end{array}$

$\begin{array}{ll}\text { Conclusion } & 167\end{array}$

6 Positive action 170

Emily Driver

$\begin{array}{ll}\text { Political power } & 170\end{array}$

Emotional power 173

Power over our emotions $\quad 175$

$\begin{array}{ll}\text { A child-centred approach } & 179\end{array}$

Detection and recognition of child sexual abuse $\quad 180$

Conclusion 196

$\begin{array}{ll}\text { Further reading } & 201\end{array}$ 


\title{
Acknowledgements
}

This book evolved over a two-year period during which the editors gained invaluable help and inspiration from several groups and individuals. We would like to thank women's groups such as A Woman's Place, the London women's centre; the Child Sexual Abuse Preventive Education Project, London; the Incest Survivors' Campaign, UK; and TABOO, the Manchester refuge for girls. Emily Driver is grateful for advice from Tabitha, Benedict and Felix Driver; Jane Fleming; Liz Hunter; Hilary Kelly; Kim Porter; Isabelle Postill; and workers at the Camden Community Law Centre, especially Russell Campbell. Audrey Droisen is grateful to Aqeela, Ann, Debbie, Diane, Effie, Elizabeth, Ellen, Kris and Leah.

We wish to dedicate this book to Anne Driver and Paula Bartley, in gratitude for their support.

\author{
EMILY DRIVER \\ Audrey Droisen
}




\section{Notes on the contributors}

Emily Driver recently qualified as a barrister. She graduated with a degree in Russian and Ancient Greek from Oxford University in 1980 and went on to complete a Diploma in Comparative Slavonic Studies (specialising in linguistics). She then worked as a lexicographer, with a particular interest in learners' dictionaries, for seven years, during which time she was actively involved in the British women's movement and helped to found both the Incest Survivors' Campaign and the Child Sexual Abuse Preventive Education Project in the UK. She has trained professionals in the field and counselled abused children. She worked as a play therapy consultant to Social Services Departments in London until recently and is now embarking on a legal practice in London, concentrating on criminal and family law.

Audrey Droisen is an independent film producer and director. Her work included Redundant Women, A Crime of Violence (a programme on child sexual abuse) and Bitter Wages. She is also a member of the Advisory Group for the Child Abuse Studies Unit at the Polytechnic of North London and a member of the Feminist Coalition Against Child Sexual Abuse.

Dympna House is a feminist incest counselling centre in Sydney, Australia. The Centre, which is community- and not governmentbased, was set up in December 1983 by Sydney Women Against Incest. These women, from both non-government and government services, ran a three-day telephone incest survey from Dympna House in February 1984. The publicity and awareness generated by this phone-in led to the establishment, by the State government, of the New South Wales Child Sexual Assault Taskforce. Its recommendations are now being implemented by the NSW Child 
Protection Council, and include legal reforms, development of counselling services, training, and a multi-lingual community education campaign. Part of this campaign is aimed at men, with huge billboards all over New South Wales saying 'Child sexual assault offenders - no excuses, never ever'.

Simmy Viinikka is a solicitor living and working in south-east London specialising in family law. Over the past ten years she has been actively involved in a number of feminist campaigns and organisations, particularly around the issue of sexual violence. She has been a member of two Rape Crisis Centres and a Women's Aid Refuge. Professionally, she acts in many cases where the sexual abuse of children is an issue, and is trying to develop a feminist approach to legal practice. 